\title{
Local, non-systemic, and minimally invasive therapies for calcinosis cutis: a systematic review
}

\author{
Joanna Nowaczyk ${ }^{1}$ (i) $\cdot$ Michał Zawistowski $^{1}$ (i) $\cdot$ Piotr Fiedor $^{1}$
}

Received: 25 April 2021 / Accepted: 11 June 2021 / Published online: 24 June 2021

(c) The Author(s) 2021

\begin{abstract}
Calcinosis cutis is a deposition of calcium in the skin and subcutaneous tissue, often accompanied by pain, reduced mobility, and chronic infections. Limited evidence is available about the feasibility and efficacy of therapies alternative to systemic treatment and surgical excision, both of which often lead to unsatisfactory results or complications. We conducted a systematic review to evaluate the efficacy and safety of topical and intralesional sodium thiosulfate, extracorporeal shockwave lithotripsy (ESWL), and laser for calcinosis cutis. PubMed, Embase, and Web of Science were searched. Reports of calciphylaxis and treatment combined with systemic medications were excluded. A total of 40 studies including 136 patients were analysed. Partial or complete remission after monotherapy was observed in $64 \%$ to $81 \%$ of cases. Self-applied topical sodium thiosulfate required patient's adherence (mean treatment duration, 4.9 months; range 2-24). Laser therapy enabled complete remission of microcalcifications after a single procedure $(57 \% ; 12 / 21)$. ESWL and intralesional sodium thiosulfate injections decreased calcinosis-associated pain (median reduction in VAS score, 3 ; range $0-9$ and 1 ; range $0-5$, respectively). The most common adverse event was scarring and hyperkeratosis, observed after $\mathrm{CO}_{2}$ laser $(56 \% ; 10 / 18)$. Intralesional sodium thiosulfate injections caused transient pain in over $11 \%$ of patients. Recurrences within the follow-up were rare $(2 \% ; 3 / 136)$. This study provides an overview of minimally invasive and local therapies that in selected cases might transcend conventional treatment. The limitation of this study is the poor level of evidence, which emerges mainly from non-randomized studies at high risk of bias.
\end{abstract}

Keywords Calcinosis cutis · Calcifications · Extracorporeal shockwave lithotripsy $\cdot$ Laser $\cdot$ Sodium thiosulfate $\cdot$ Minimally invasive surgical procedures

\section{Introduction}

Calcinosis cutis (CC) is a cutaneous and subcutaneous deposition of insoluble salts of calcium. Depending on the underlying cause, calcifications are classified into four types: dystrophic (e.g. caused by trauma or connective tissue disease), metastatic (e.g. in chronic kidney disease), iatrogenic (e.g. after intravenous fluids extravasation), and idiopathic (formed without any apparent reason) [1]. A severe course of disease is often associated with pain, reduced range of motion, ulcerations, cosmetic concerns, and recurrent infections [2, 3], that may even result in extremity amputation

Piotr Fiedor

piotrfiedor@wp.pl

1 Department of General and Transplantation Surgery, Medical University of Warsaw, Nowogrodzka 59, 02-006 Warsaw, Poland
[4] and mental health problems. Poor quality of life and significant disability are the main concerns of patients with advanced CC.

Based on limited evidence about numerous therapies reported, definitive treatment recommendations for $\mathrm{CC}$ have not been established $[3,5,6]$. Data regarding the efficacy of several off-label oral and intravenous drugs are inconsistent $[7,8]$ and their use is limited by such factors as: severity of the underlying disease, drug interactions, increased risk of severe adverse events, and the need for institutional review board approval. In these situations, treatment applied locally may be more suitable due to a minimal systemic influence [9]. Surgical extraction is often successful, nonetheless carries the risk of complications due to tissue injury, yet recurrence of the lesion [6, 7]. Excision of large lesions may require muscle amputation $[4,10]$ and skin grafting $[11,12]$, while surgical removal of fingertip calcifications may cause 
digital neurovascular bundle damage and limited mobility $[2,7,12-14]$.

In this systematic review, we summarised the current knowledge about minimally invasive and local treatments for $\mathrm{CC}$, including laser therapy, extracorporeal shockwave lithotripsy (ESWL), topical (top-STS) and intralesional sodium thiosulfate (IL-STS).

\section{Materials and methods}

\section{Protocol and registration}

This study is based on a prospectively written protocol that has been registered on PROSPERO (CRD42020207253). Results are reported in compliance with the PRISMA statement [15].

\section{Search strategy}

We searched PubMed, Embase, and Web of Science for eligible studies. The search was complemented by the manual screening of papers' references. Additional search information is summarised in the Supplementary Content.

\section{Eligibility criteria}

Studies reporting the use of top-STS, IL-STS, ESWL, and all kinds of laser therapies for $\mathrm{CC}$ were considered eligible for inclusion. Full-text articles as well as conference abstracts of acceptable quality in English, Spanish, or German were evaluated. Studies reporting patients with calciphylaxis as well as individuals treated with a combination of systemic and local or minimally invasive treatment were excluded at the screening stage.

\section{Data extraction}

Two reviewers independently screened the records yielded by the search. Discrepancies were resolved by discussion among all co-authors. The following variables were extracted from the articles: type of study, number of patients, their age, sex, main and additional diagnoses, location and size of the lesions, duration of the symptoms, additional features of the lesions (e.g. ulceration), type of therapy used for calcinosis cutis (with dosage, regimen, and route of administration), follow-up, outcomes of the therapy, adverse effects, previous treatment used for calcinosis cutis, and the underlying cause of calcinosis. Additionally, we extracted any available information about indications and contraindications of the evaluated therapies. The outcomes of the treatment were divided into four categories: complete response (i.e. when calcifications resolved in 100\%), partial response (any response other than 0 and 100\%), no response, and unknown response (in case of patients who were lost to follow-up for any reason).

\section{Risk of bias}

The risk of bias was assessed with the Joanna Briggs Institute's critical appraisal tools [16]. The overall bias was ranked as low when $>75 \%$ of questions were answered "Yes", high if the prevalence was $<50 \%$, and moderate otherwise.

\section{Data analysis}

We extracted data of individual patients from each study and summarized the outcomes of all evaluated treatment modalities with the descriptive statistics. We reported medians with ranges for continuous variables and frequencies for categorical variables. Missing data were managed by mean imputation.

\section{Results}

\section{Study selection}

A total of 410 articles were retrieved from the search. Additionally, ten more studies were added after the manual screening of the reference sections [10, 17-25]. Eight articles were excluded at the eligibility stage due to reporting patients described in other included studies [20, 26, 27] or insufficient data [24, 25, 28-30]. In the selection process, 40 records met the eligibility criteria and were included in this systematic review (Fig. 1). Details of the included studies are specified in Table 1.

\section{Quality assessment}

Included articles consisted of one prospective double-blind placebo-controlled pilot study [22], 7 case series [4, 5, 10, $13,17,18,21,31-35]$, and 27 case reports [36-44]. Five conference abstracts were included [19, 21, 33, 45, 46]. In two studies only, a control group was present and defined as another lesion in the same patient [22,34]. The overall risk of bias was ranked as low in 10 studies, moderate in 19 , and high in 11 (Supplementary Content).

\section{Patients' characteristics}

A total of 136 patients with CC were evaluated in this systematic review. The youngest was a neonate while the eldest was 91 years old. Man to woman ratio was 21:90 (sex of 25 patients was not reported). Majority of patients 


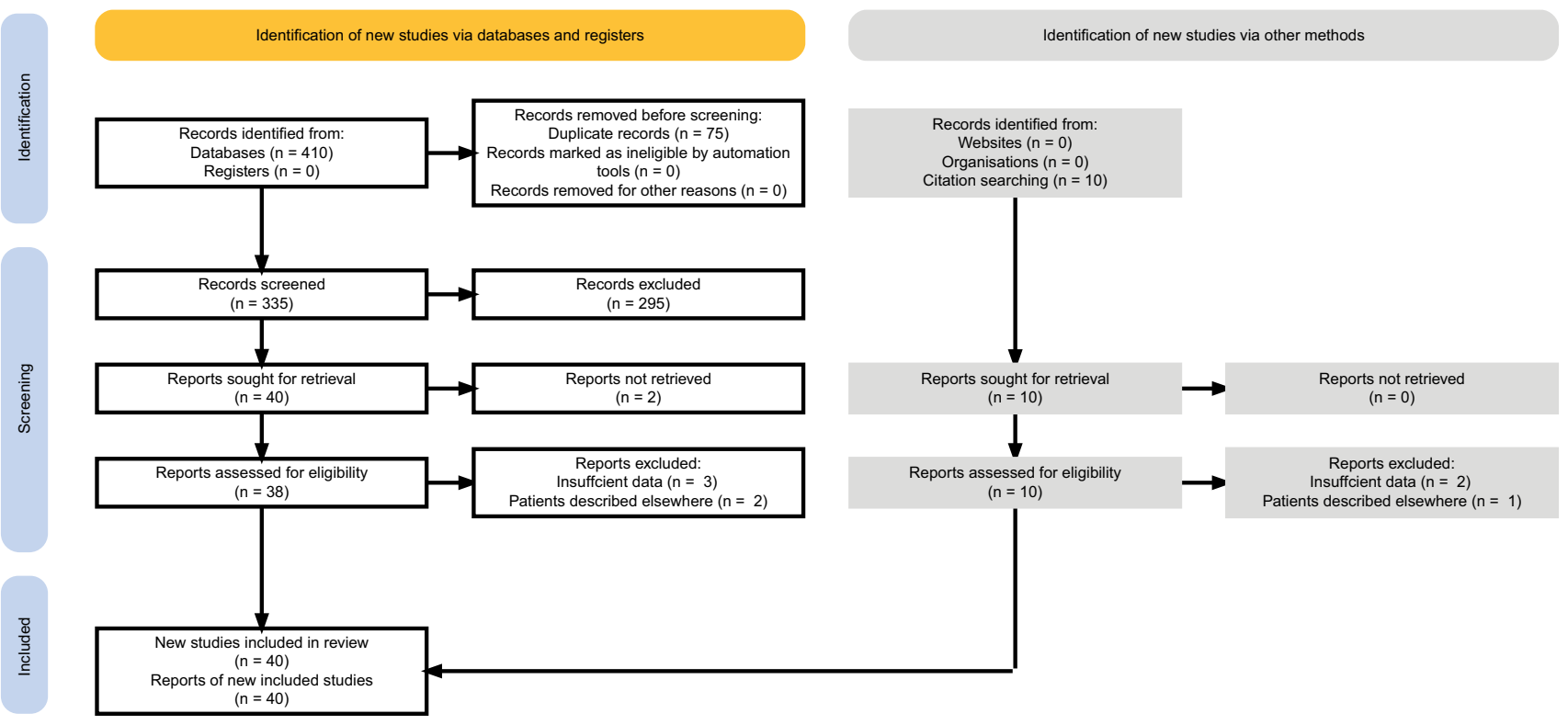

Fig. 1 PRISMA flowchart illustrating the process of data screening

had an underlying cause of CC, most commonly an autoimmune connective tissue disease. Predominantly, patients were diagnosed with systemic sclerosis $(n=71)$, dermatomyositis or juvenile dermatomyositis $(n=16)$, and overlap syndrome $(n=7)$. The duration of $\mathrm{CC}$ symptoms ranged from a few days (in case of extravasation) to 30 years (in systemic sclerosis). All lesions were clinically assessed by a physician before and after the treatment. Calcifications were observed throughout the body (extremities, trunk, pelvic area, earlobes, and eyelids) and were often characterised by the presence of ulceration, infection, pain, and limited mobility.

\section{Treatment modalities}

Top-STS was prescribed as a compounded drug due to the absence of commercial products on the market. Formulation base was prepared from cold cream $(n=17)$, zinc ointment $(n=27)$, gel base $(n=1$, in a patient allergic to zinc), petrolatum $(n=1)$, and lotion $(n=1)$. Compresses soaked with sodium thiosulfate (STS) were used in one case alternately with acetic acid dressings and steroid ointment applied around the wound edges [47]. In some studies, the treated areas were left under occlusion. Concentration of STS in the formulas was $10 \%(n=18), 20 \%(n=1)$, or $25 \%(n=30)$. In one case, the concentration used was gradually increased from 3 to $10 \%$ over 2 weeks [48], while in another, the concentration was increased from 25 to $50 \%$ after 1 year of treatment [31]. In one study, reported STS doses corresponded to $370 \mathrm{mg}$ and $833 \mathrm{mg}$ per day [18].
The use of IL-STS was reported at the following concentrations: $0.1 \mathrm{mg} / \mathrm{ml}(n=7), 40 \mathrm{mg} / \mathrm{ml}(n=5), 150 \mathrm{mg} / \mathrm{ml}$ $(n=31)$, and $250 \mathrm{mg} / \mathrm{ml}(n=7)$. Doses of STS ranged from $9.27 \mathrm{mg}$ to $3000 \mathrm{mg}$ per appointment and depended on the lesion sizes and patients' tolerance as the injections might be painful despite anaesthesia $[9,10]$.

In patients treated with $\mathrm{CO}_{2}$, Er:YAG, and diode lasers only one session was required [13, 23, 35, 35, 44, 49-54]. One patient who underwent therapy with a picosecond laser followed by a $\mathrm{CO}_{2}$ laser required three sessions [55]. Among the $\mathrm{CO}_{2}$ lasers, the ultrapulse variant was most commonly reported. Configuration of the laser settings was vast and unfeasible to summarise.

Some studies indicated the use of ESWL in both focalised and non-focalised modes with 2500-3000 shock waves and the power of 896-929 V per treatment (energy of $0.1-0.3 \mathrm{~mJ} / \mathrm{mm}^{2}$ ) [5, 56, 57]. Calcifications could be located by a fluoroscopic amplification device coupled to the lithotripter [5].

Pavlov-Dolijanovic et al. [58] used combined therapy consisting of 6 sessions of ESWL at weekly intervals followed by a 6 -week break and continued with 4 weekly ILSTS injections $(150 \mathrm{mg} / \mathrm{ml})$. Eleryan et al. [34] reported the use of 6 and 7 monthly sessions of picosecond laser followed by application of $4 \mathrm{~mL}$ of $5 \%$ top-STS.

\section{Outcomes of the treatment}

Improvement was achieved in $81 \%$ (39/48) of cases treated with top-STS and 74\% (39/53) with IL-STS. In those who underwent ESWL and laser therapies, response to 


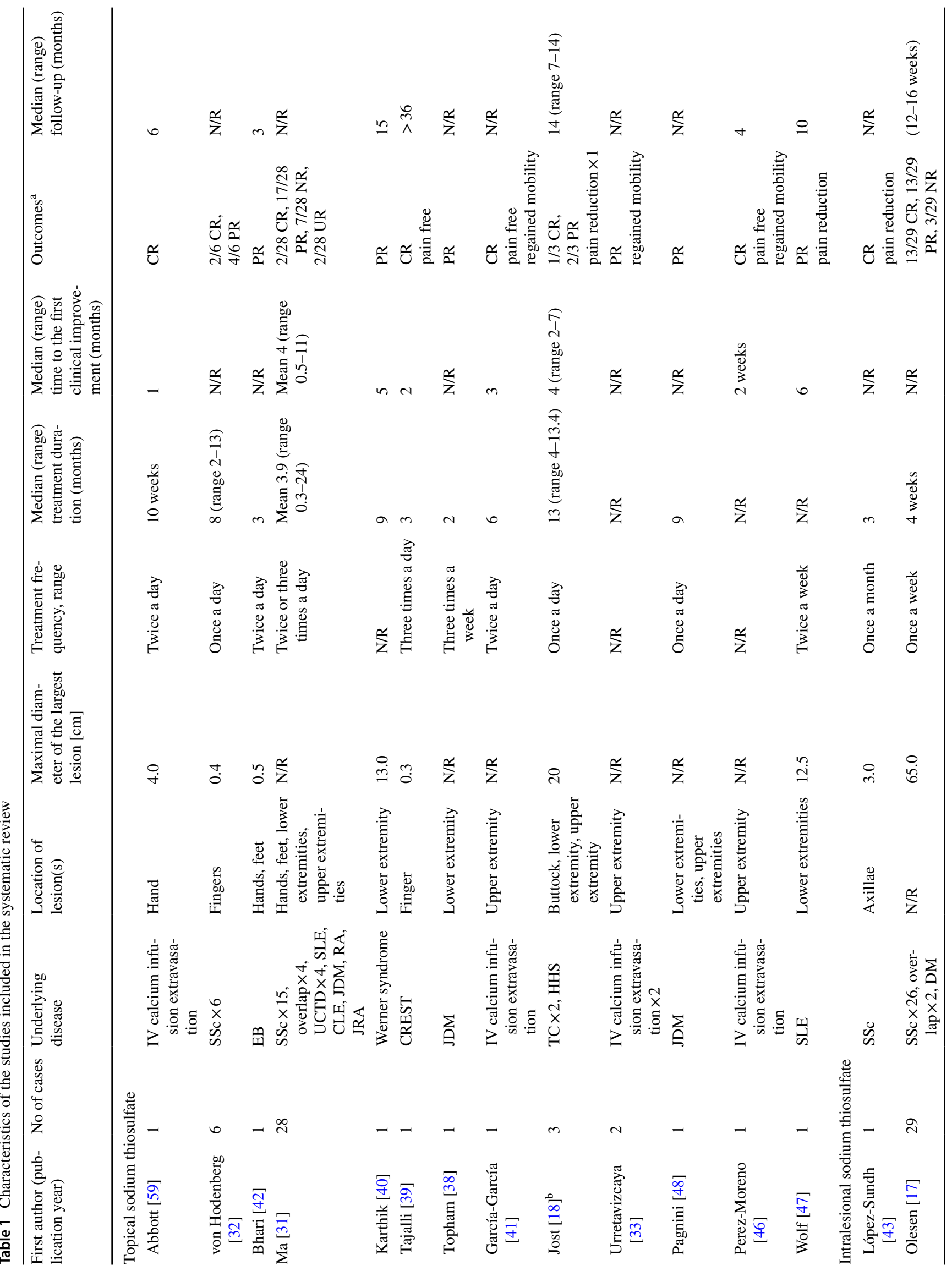




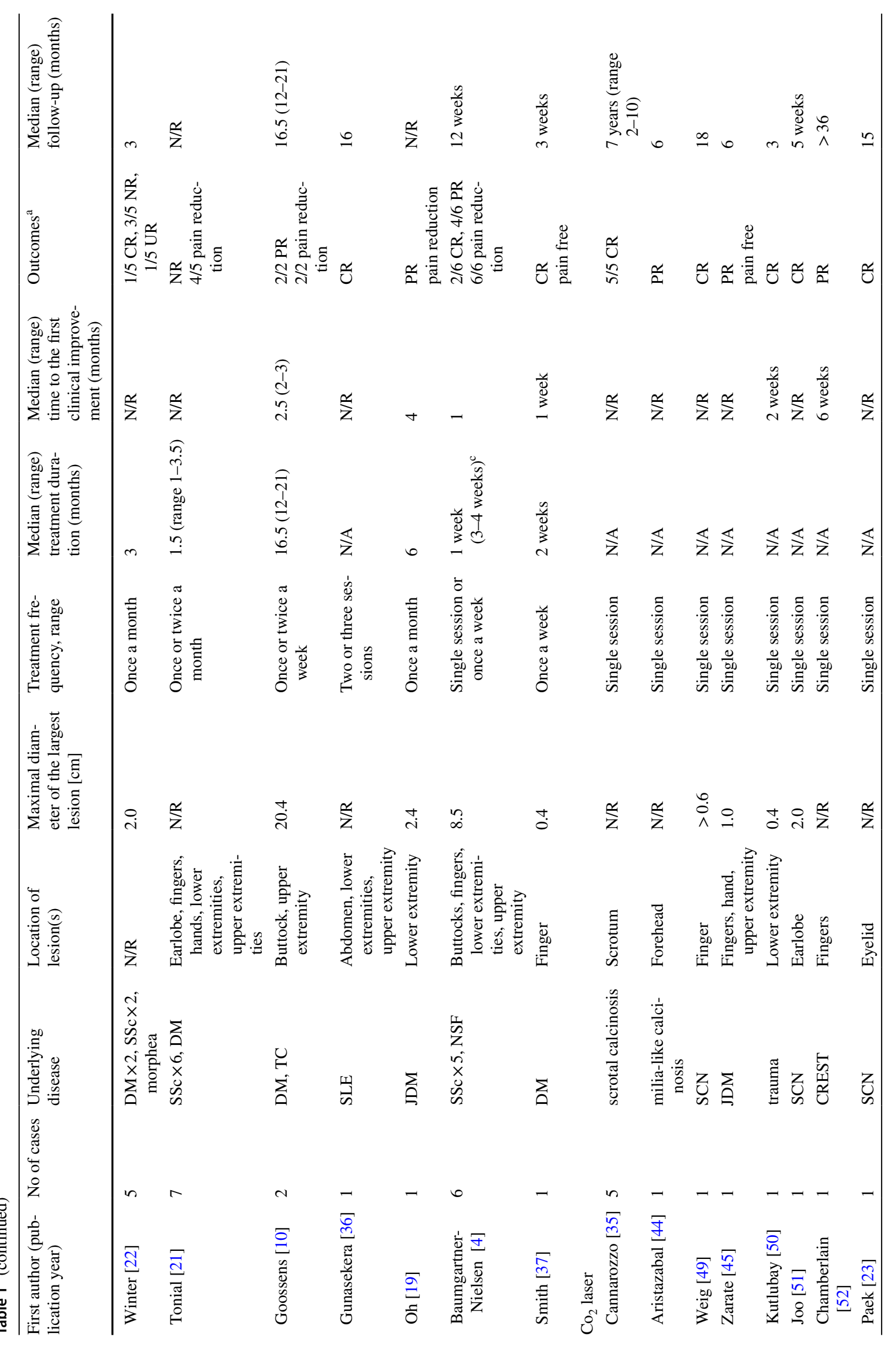




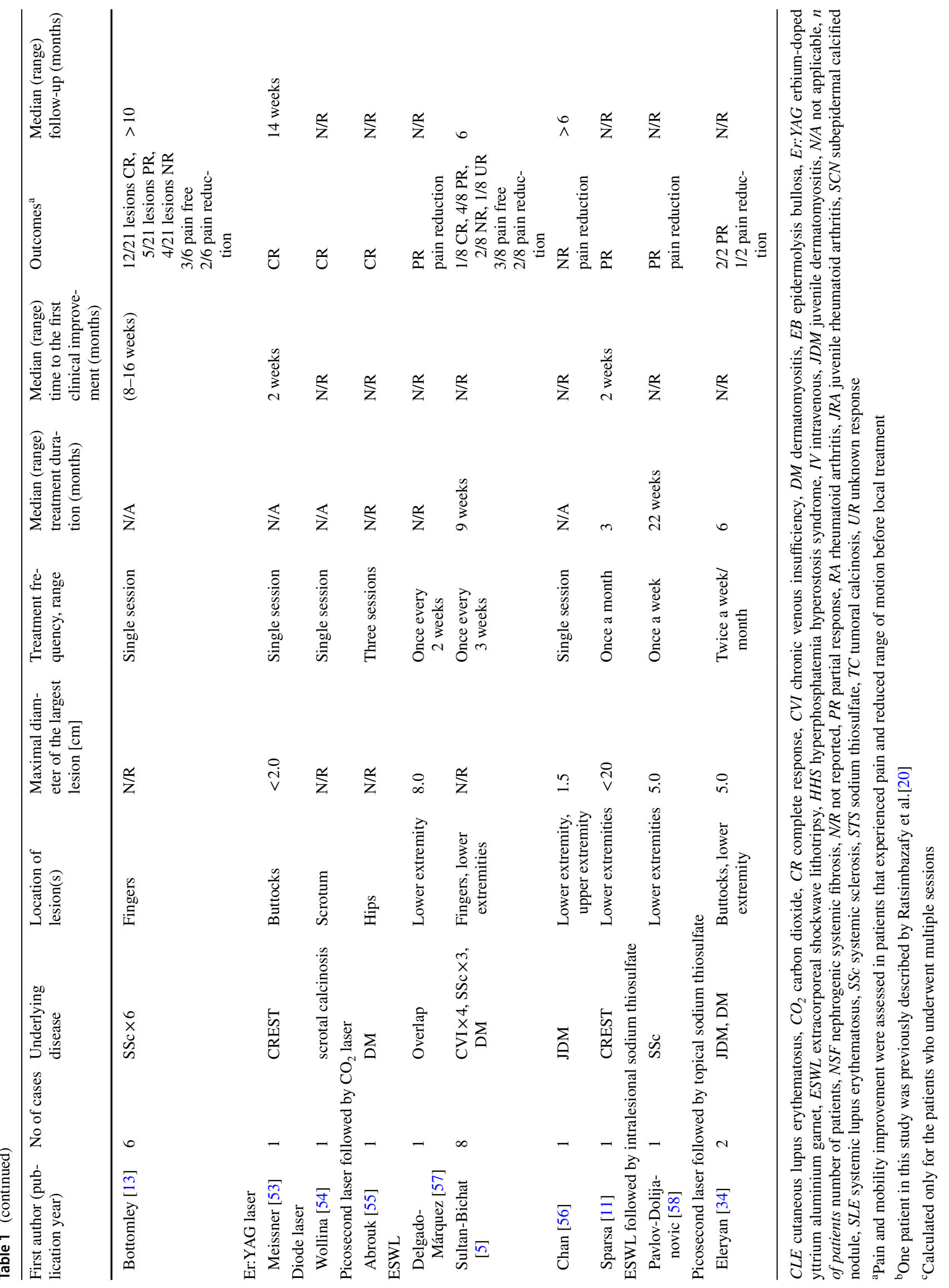


treatment was observed in 64\% (7/11) and 71\% (15/21) of cases, respectively. The patients who were subject to the ESWL therapy combined with IL-STS and picosecond laser followed by top-STS had partial remission. Detailed information about the outcomes is provided in Table 2.

Patients who experienced partial or complete reduction in pain were reported mainly in the ESWL (pain-free, 3/10; reduced pain, 4/10) and laser (pain-free, 4/9; reduced pain, 2/9) subgroups. Data regarding pain control were poorly reported for STS. Median pain reduction measured in the VAS scale was 3 (range 0-9) in six patients treated with ESWL, 1 (range 0-5) in five patients managed with IL-STS, and 8 in the patient managed with ESWL followed by IL-STS.

\section{Perioperative management}

Intradermal or topical anaesthesia was utilised during ILSTS [10], $\mathrm{CO}_{2}[13,35,44,52]$, and Er:YAG laser procedures [53]. Some patients were prescribed with nonsteroidal anti-inflammatory drugs or paracetamol after the procedure. Postoperative management included an ointment or cream of

Table 2 Summary of local, non-systemic, and minimally invasive treatment options for calcinosis cutis

\begin{tabular}{|c|c|c|c|c|c|c|c|}
\hline $\begin{array}{l}\text { Treatment modal- } \\
\text { ity }\end{array}$ & $n$ & $\begin{array}{l}\text { Maximal diam- } \\
\text { eter of the largest } \\
\text { lesion }(\mathrm{cm})\end{array}$ & $\begin{array}{l}\text { Treatment fre- } \\
\text { quency, range }\end{array}$ & $\begin{array}{l}\text { Median (range) } \\
\text { treatment dura- } \\
\text { tion } \\
\text { (months) }^{\mathrm{a}}\end{array}$ & $\begin{array}{l}\text { Median (range) } \\
\text { time to the first } \\
\text { clinical improve- } \\
\text { ment (months) }\end{array}$ & $\begin{array}{l}\text { Response rates, } \\
\%, n / N\end{array}$ & $\begin{array}{l}\text { Adverse events } \\
\text { (number of } \\
\text { patients) }\end{array}$ \\
\hline \multicolumn{8}{|l|}{ STS } \\
\hline Topical & 48 & 13 & $\begin{array}{l}\text { Twice a week to } \\
\text { three times a } \\
\text { day }\end{array}$ & $3.9(0.3-24)$ & $4.0(0.5-11)$ & $\begin{array}{l}\text { Complete, 19, } \\
\text { 9/48 } \\
\text { Partial, 63, 30/48 } \\
\text { None, 6, 3/48 } \\
\text { Unknown, 13, } \\
\text { 6/48 }\end{array}$ & $\begin{array}{l}\text { Transient pruritus } \\
\text { (1), recurrence } \\
\text { (1), skin irrita- } \\
\text { tion (2), zinc } \\
\text { ointment allergy } \\
\text { (1) }\end{array}$ \\
\hline Intralesional & 53 & 65 & $\begin{array}{l}\text { Single session to } \\
\text { once a month }\end{array}$ & $1.0(0.5-21)$ & $1.0(0.25-4)$ & $\begin{array}{l}\text { Complete, } 36, \\
\quad 19 / 53 \\
\text { Partial, 38, 20/53 } \\
\text { None, 25, 13/53 } \\
\text { Unknown, 2, 1/53 }\end{array}$ & $\begin{array}{l}\text { Infection }(5) \text {, } \\
\text { injection pain } \\
\left(6^{b}\right), \text { blistering } \\
(1) \text {, skin discol- } \\
\text { oration (N/R) }\end{array}$ \\
\hline \multicolumn{8}{|l|}{ Laser } \\
\hline $\mathrm{CO}_{2}$ & 18 & 2.0 & $\begin{array}{l}\text { One to three ses- } \\
\text { sions }\end{array}$ & $\mathrm{N} / \mathrm{A}^{\mathrm{c}}$ & $\mathrm{N} / \mathrm{A}^{\mathrm{c}}$ & $\begin{array}{l}\text { Complete, } 57 \text {, } \\
12 / 21\end{array}$ & \multirow{4}{*}{$\begin{array}{l}\text { Infection (2), } \\
\text { recurrence }(2), \\
\text { scaring or hyper- } \\
\text { keratosis }(10), \\
\text { hypopigmenta- } \\
\text { tion (2), itching } \\
\text { or burning (2) }\end{array}$} \\
\hline Er:YAG & 1 & $<2.0$ & & & & Partial, 14, 3/21 & \\
\hline Diode & 1 & $\mathrm{~N} / \mathrm{R}$ & & & & Unknown, 29, & \\
\hline $\begin{array}{l}\text { Picosec- } \\
\text { ond }+\mathrm{CO}_{2}\end{array}$ & 1 & $\mathrm{~N} / \mathrm{R}$ & & & & $6 / 21^{a}$ & \\
\hline ESWL & 11 & $<20.0$ & $\begin{array}{l}\text { Single session to } \\
\text { twice a month }\end{array}$ & $2.25(1-2.25)$ & $N / A^{c}$ & $\begin{array}{l}\text { Complete, 9, 1/11 } \\
\text { Partial, 55, 6/11 } \\
\text { None, 27, 3/11 } \\
\text { Unknown, 9, 1/11 }\end{array}$ & Transient fever (1) \\
\hline \multicolumn{8}{|l|}{ Combined } \\
\hline $\begin{array}{l}\text { ESWL + intral- } \\
\text { esional STS }\end{array}$ & 1 & 5.0 & Once a week & 5.5 & $\mathrm{~N} / \mathrm{R}$ & Partial, 100, 1/1 & $\begin{array}{l}\text { Crater-like defects } \\
(\mathrm{N} / \mathrm{R})\end{array}$ \\
\hline $\begin{array}{l}\text { Picosec- } \\
\text { ond + topical } \\
\text { STS }\end{array}$ & 2 & 5.0 & $\begin{array}{c}\text { Twice a week to } \\
\text { twice a month }\end{array}$ & 6.0 & $\mathrm{~N} / \mathrm{R}$ & Partial, 100, 2/2 & None \\
\hline
\end{tabular}

Er:YAG erbium-doped yttrium aluminium garnet, ESWL extracorporeal shockwave lithotripsy, N/A not applicable, $N / R$ not reported, $S T S$ sodium thiosulfate

${ }^{a}$ Missing data were managed by available case analysis and mean imputation was used when a mean was known for a variable of interest but exact values were not reported for individual cases from a single study

${ }^{b}$ Olesen et al. [17] also reported injection pain, however, without an exact number of cases experiencing it

${ }^{\mathrm{c}}$ A group of patients was too small

${ }^{\mathrm{d}}$ Bottomley et al. [13] reported outcomes as for particular lesions instead of describing overall response in each patient 
healing and soothing properties [55], often combined with antimicrobials such as chlorhexidine [50], mupirocin [13, 52], fusidic acid [35, 44], and povidone-iodine [53].

\section{Adverse effects}

Infection was recognised in $9 \%(5 / 53)$ of patients after ILSTS $[4,10,17]$ and in $11 \%(2 / 18)$ of cases managed with $\mathrm{CO}_{2}$ laser (no infectious complications were reported for other types of lasers) [13]. Infections were managed with antibiotics [10, 47]. Injection-associated pain was transient and occurred in over $11 \%$ of patients receiving IL-STS. Either scaring or hyperkeratosis was noticed in 56\% (10/18) of patients after $\mathrm{CO}_{2}$ laser treatment $[13,35,50]$. Furthermore, three recurrences within a few months were observed after top-STS and $\mathrm{CO}_{2}$ laser therapies [13, 18]. In one such case, the calcifications recurred after a trauma [18]. One case of transient fever was the only adverse reaction observed after ESWL [56]. Adverse effects of each treatment modality are specified in Table 2.

\section{Discussion}

This review summarises the current evidence about the local and minimally invasive therapies for calcinosis cutis. A single treatment modality lead to a partial or complete remission in the majority of patients (from 64 to $81 \%$ ). Combined treatment was reported only for three patients to date. Small calcifications (the largest reported length of $4 \mathrm{~cm}$ [59]) can be completely treated locally, although recalcitrant CC may require systemic therapy. The results of local therapies for idiopathic and iatrogenic $\mathrm{CC}$ are especially promising (87\% complete response, 13/15), potentially owing to the absence of further triggering factors for formation of calcifications. Available evidence speaks for safety of local methods owing to manageable mild side effects and absence of severe adverse reactions.

\section{STS}

STS is a substance known for its use in cyanide poisoning, cisplatin toxicity [18], and calciphylaxis [60]. Its use for CC is justified, as STS is presumed to act as a chelating agent that increases calcium solubility up to 100,000 times $[4,59,61]$. Taking into account the supposed mechanism of action, its impact on bone mineralisation should be investigated, especially in the paediatric population [18]. Additionally, anti-inflammatory (hydrogen sulfide production), vasodilative (nitric oxide synthase regeneration), and antioxidative (reduction of free radicals) properties of STS may support tissue healing in CC [18, 41, 59]. Intravenous STS may be used for $\mathrm{CC}$, however, this route of administration is considered impractical $[10,30]$ and have moderate to life-threatening adverse events, such as headaches, vomiting, metabolic acidosis, hypotension, and hypernatremia [4, $10,18,41]$.

Top-STS shows promising outcomes ( $81 \%$ response rate) and seems to have the least systemic influence among the local treatments for CC. Nonetheless, patient compliance is required owing to longer duration of treatment compared to other modalities (Table 2). Apparently, topical route and drug self-application might facilitate the long-term adherence in comparison to injections and oral treatment [18, 32]. Top-STS may be investigated as potential treatment for lesions disqualified from conventional surgery (i.e. disseminated and extensive lesions and these located in anatomically critical sites $[5,17,62])$. Some patients with a history of unsuccessful therapy with top-STS respond to IL-STS [10, 30], laser [45], and ESWL [57]. Interestingly, a similar compound, sodium metabisulfite in concentration of $25 \%$, was suggested as an effective alternative to STS $[63,64]$.

STS absorption into the bloodstream after intralesional injection seems to be of low level as the untreated lesions of patients receiving this therapy remained unchanged and no alterations in anion gap, eGFR, calcium, bicarbonate, and chloride serum levels were observed [10]. High complete response rates (of 36\%) observed after IL-STS may result from increased concentrations of the active substance in the lesion site when compared to other routes of administration [10]. IL-STS may facilitate the treatment of CC in patients with thickened skin in systemic sclerosis, which is an obstacle for an accurate surgical removal [13]. Transient injectionassociated pain was a common adverse effect (in over $11 \%$ ). Healing lesions may be prone to infection (9\%, emerging mainly from the skin microbiome) due to softened calcifications [10] and injury caused by the injection. Some patients experienced less pain after completed therapy (median VAS scale reduction of 1, range $0-5$ ), despite unsuccessful size reduction of calcifications [21]. Twelve patients reported by Winter et al. [22] (with control lesions) and Tonial et al. [21] demonstrated no significant change in size after 3-8 IL-STS injections, although low doses and long injection intervals could disadvantage the treatment efficacy in these studies.

\section{Laser treatment}

Laser therapy is considered less invasive, faster, and more convenient than conventional surgery for both patients and clinicians. A single session is usually enough for the complete removal of small calcifications (up to $2 \mathrm{~cm}$ long [51]). No recurrences were observed within the follow-up, in contrast to conventional surgery, when the soft tissue injury from procedure may induce the formation of new lesions $[2,12,14,17]$. Spontaneous extrusion of the chalky exudate (expelling the softened calcium deposits) after laser therapy 
and ESWL is considered as a good sign of the healing process $[5,55]$. In comparison to curettage, laser treatment helps to achieve a good haemostasis by closing capillaries, which ensures a clear operating field [13, 52]. Excellent aesthetic results with a minimal scar may be achieved by the use of precise laser vaporisation [14, 52]. Lower risk of thermal damage is associated with Er:YAG laser as it has ten times greater absorption than $\mathrm{CO}_{2}$ laser and encourages wound healing [53]. In one study, picosecond laser was used as an assisted drug delivery for top-STS, achieving partial regression of calcifications [34]. Skin discoloration or scarring was a common side effect (56\%). Infections and recurrences were also noted in several cases (11\% for both events).

\section{ESWL}

ESWL is a minimally invasive procedure with a low risk of adverse effects. It is widely used for urolithiasis and calcific tendonitis [5, 11, 56, 57], or adjuvantly for wound healing [65]. This procedure seems the most effective for ulcerated or radiopaque (calcium oxalate or dihydrate) calcinosis on small areas, regardless the location and underlying disease [5]. Its efficacy is lower for thick and extensive plaques or calcifications showing radio-transparency (cystine or uric acid) [5]. ESWL destroys the structure of calcifications without their mechanical extraction [11] and for that reason a prior use of ESWL may facilitate a surgical extraction of calcifications [5]. ESWL is effective for larger calcifications (up to $20 \mathrm{~cm}$ long [11]), however, it leads only to a partial reduction in size (in 55\%, while complete remission is noted only in about 7\%) [56, 57]. ESWL shows a satisfactory analgesic effect (median VAS scale reduction of 3, range 0-9), possibly owing to the fragmentation of calcified lesions that compress nerves and tissues [5]. This method could be, therefore, considered as a pain relief and palliative treatment for CC, especially as an opioid-sparing strategy for extensive and painful lesions [56]. Assessment of the true efficacy of ESWL combined with IL-STS is necessary as these methods could possibly complement each other [58]. A limitation of ESWL is the decreased accessibility to some lesions in individuals with limited mobility as positioning of patients was primarily designed for urologic conditions [5].

\section{Limitations}

Studies reporting the treatment of CC present a low level of evidence due to the lack of high quality and adequately powered randomized controlled trials and the absence of head-to-head studies, which results from the low prevalence of CC $[41,59]$. Thus, this review is based on weak evidence. Despite that, we believe it may have some value for clinicians looking for guidance in the management of this rare disease.

\section{Conclusion}

This study provides an overview of local and minimally invasive therapies that could become the life-changing treatment for selected patients with $\mathrm{CC}$, with potential better safety and non-inferior efficacy to systemic drugs and surgical excision. Insufficient evidence is currently available to provide strong recommendations regarding these treatment modalities. For pain reduction, ESWL and IL-STS may be considered. Convenient self-application at home is an advantage of top-STS. Lasers are highly effective for solitary microcalcifications. Disadvantages of IL-STS include transient pain during injection. Clinical trials are required for further confirmation of these findings.

Supplementary Information The online version contains supplementary material available at https://doi.org/10.1007/s00403-021-02264-5.

Acknowledgements The authors would like to thank Dr Mariusz Sikora from the Department of Dermatology at the Medical University of Warsaw for his valuable comments regarding the manuscript.

Author contributions $\mathrm{JN}$ and $\mathrm{MZ}$ designed this study, searched medical databases, and extracted the data from literature. PF participated in discussion regarding any discrepancies. All authors interpreted the results. $\mathrm{JN}$ and MZ drafted the manuscript which was revised and approved by all authors.

Funding None.

\section{Declarations}

Conflict of interest The authors declare that they have no conflict of interest.

IRB approval status Not applicable.

Disclosures The information included in this article was not presented before by any of the authors.

Open Access This article is licensed under a Creative Commons Attribution 4.0 International License, which permits use, sharing, adaptation, distribution and reproduction in any medium or format, as long as you give appropriate credit to the original author(s) and the source, provide a link to the Creative Commons licence, and indicate if changes were made. The images or other third party material in this article are included in the article's Creative Commons licence, unless indicated otherwise in a credit line to the material. If material is not included in the article's Creative Commons licence and your intended use is not permitted by statutory regulation or exceeds the permitted use, you will need to obtain permission directly from the copyright holder. To view a copy of this licence, visit http://creativecommons.org/licenses/by/4.0/. 


\section{References}

1. Gutierrez A Jr, Wetter DA (2012) Calcinosis cutis in autoimmune connective tissue diseases. Dermatol Ther 25:195-206. https:// doi.org/10.1111/j.1529-8019.2012.01492.x

2. Touart DM, Sau P (1998) Cutaneous deposition diseases. Part II J Am Acad Dermatol 39:527-544. https://doi.org/10.1016/S01909622(98)70001-5

3. Pai S, Hsu V (2018) Are there risk factors for scleroderma-related calcinosis? Mod Rheumatol 28:518-522. https://doi.org/10.1080/ 14397595.2017.1349594

4. Baumgartner-Nielsen J, Olesen AB (2016) Treatment of skin calcifications with intra-lesional injection of sodium thiosulphate: a case series. Acta Derm Venereol 96:257-258. https://doi.org/10. 2340/00015555-2206

5. Sultan-Bichat N, Menard J, Perceau G et al (2012) Treatment of calcinosis cutis by extracorporeal shock-wave lithotripsy. J Am Acad Dermatol 66:424-429. https://doi.org/10.1016/j.jaad.2010. 12.035

6. Balin SJ, Wetter DA, Andersen LK, Davis MDP (2012) Calcinosis cutis occurring in association with autoimmune connective tissue disease: the Mayo Clinic experience with 78 patients, 1996-2009. Arch Dermatol 148:455-462. https://doi.org/10.1001/archdermat ol.2011.2052

7. Traineau H, Aggarwal R, Monfort J-B et al (2020) Treatment of calcinosis cutis in systemic sclerosis and dermatomyositis: a review of the literature. J Am Acad Dermatol 82:317-325. https:// doi.org/10.1016/j.jaad.2019.07.006

8. Valenzuela A, Song P, Chung L (2018) Calcinosis in scleroderma. Curr Opin Rheumatol 30:554-561. https://doi.org/10.1097/BOR. 0000000000000539

9. Isoherranen K, Bouchard L, Kluger N (2017) Benefits of intralesional injections of sodium thiosulfate in the treatment of calciphylaxis. Int Wound J 14:955-959. https://doi.org/10.1111/iwj. 12738

10. Goossens J, Courbebaisse M, Caudron E et al (2017) Efficacy of intralesional sodium thiosulfate injections for disabling tumoral calcinosis: two cases. Semin Arthritis Rheum 47:451-455. https:// doi.org/10.1016/j.semarthrit.2017.05.013

11. Sparsa A, Lesaux N, Kessler E et al (2005) Treatment of cutaneous calcinosis in CREST syndrome by extracorporeal shock wave lithotripsy. J Am Acad Dermatol 53:S263-S265. https://doi.org/ 10.1016/j.jaad.2005.04.010

12. Mendelson BC, Linscheid RL, Dobyns JH, Muller SA (1977) Surgical treatment of calcinosis cutis in the upper extremity. J Hand Surg 2:318-324. https://doi.org/10.1016/S0363-5023(77)80136-6

13. Bottomley WW, Goodfield MJD, Sheehan-Dare RA (1996) Digital calcification in systemic sclerosis: effective treatment with good tissue preservation using the carbon dioxide laser. Br J Dermatol 135:302-304. https://doi.org/10.1111/j.1365-2133.1996.tb011 66.x

14. Bogoch ER, Gross DK (2005) Surgery of the hand in patients with systemic sclerosis: outcomes and considerations. J Rheumatol 32:642-648

15. Page MJ, McKenzie JE, Bossuyt PM et al (2021) The PRISMA 2020 statement: an updated guideline for reporting systematic reviews. BMJ. https://doi.org/10.1136/bmj.n71

16. Aromataris E, Fernandez R, Godfrey CM et al (2015) Summarizing systematic reviews: methodological development, conduct and reporting of an umbrella review approach. Int J Evid Based Healthc 13:132-140. https://doi.org/10.1097/XEB.0000000000 000055

17. Olesen AB, Fage S (2020) Dysthrophic calcification in systemic sclerosis-intralesional injections of sodium thiosulfate may have significant positive effects on your patients. Med Res Arch. https:// doi.org/10.18103/mra.v8i5.2096

18. Jost J, Bahans C, Courbebaisse M et al (2016) Topical sodium thiosulfate: a treatment for calcifications in hyperphosphatemic familial tumoral calcinosis? J Clin Endocrinol Metab 101:2810 2815. https://doi.org/10.1210/jc.2016-1087

19. Oh Y, Kim J, Kim DY (2017) [P535] Intralesional sodium thiosulfate for the treatment of localized calcinosis cutis in juvenile dermatomyositis. Program Book 71st Autumn Meet Korean Dermatol Assoc 69:510-510

20. Ratsimbazafy V, Bahans C, Guigonis V (2012) Dramatic diminution of a large calcification treated with topical sodium thiosulfate. Arthritis Rheum 64:3826-3826. https://doi.org/10.1002/art.34628

21. Tonial AF, Cathcart MPM, Santos T et al (2018) AB0814 Sodium thiosulfate $10 \%$ intralesional to treat calcinosis in patients with systemic sclerosis and dermatomyositis: case series. Ann Rheum Dis 77:1537. https://doi.org/10.1136/annrheumdis-2018-eular. 6030

22. Winter AR, Klager S, Truong R et al (2020) Efficacy of intralesional sodium thiosulfate for the treatment of dystrophic calcinosis cutis: a double-blind, placebo-controlled pilot study. JAAD Int 1:114-120. https://doi.org/10.1016/j.jdin.2020.07.002

23. Paek SH, Kim YH, Kim DW et al (1996) Subepidermal Calcified Nodule. Ann Dermatol 8:269-271. https://doi.org/10.5021/ad. 1996.8.4.269

24. Blumhardt S, Frey DP, Toniolo M et al (2016) Safety and efficacy of extracorporeal shock wave therapy (ESWT) in calcinosis cutis associated with systemic sclerosis. Clin Exp Rheumatol 34:177-180

25. Saardi KM, Rosenstein RK, Anadkat MJ et al (2020) Calcinosis cutis in the setting of chronic skin graft-versus-host disease. JAMA Dermatol 156:814-817. https://doi.org/10.1001/jamad ermatol.2020.1157

26. Bech R, Baumgartner J, Braae-Olesen A (2018) Sodium thiosulphate is an effective treatment for dystrophic calcifications. $\mathrm{J}$ Scleroderma Relat Disord 3:241. https://doi.org/10.1177/23971 98317753491

27. Ma JE, Ernste FC, Davis MDP, Wetter DA (2018) Topical sodium thiosulfate for the treatment of calcinosis cutis associated with autoimmune connective tissue diseases: the Mayo Clinic experience, 2012-2017. J Am Acad Dermatol 79:AB299. https://doi. org/10.1016/j.jaad.2018.05.1180

28. Bair B, Fivenson D (2011) A novel treatment for ulcerative calcinosis cutis. J Drugs Dermatol 10:1042-1044

29. Fredi M, Bartoli F, Cavazzana I et al (2015) Calcinosis cutis in poly-dermatomyositis: clinical and therapeutic study. Ann Rheum Dis 74:830-831. https://doi.org/10.1136/annrheumdis-2015-eular. 4163

30. Howard RM, Smith GP (2020) Treatment of calcinosis cutis with sodium thiosulfate therapy. J Am Acad Dermatol 83:1518-1520. https://doi.org/10.1016/j.jaad.2020.06.996

31. Ma JE, Ernste FC, Davis MDP, Wetter DA (2019) Topical sodium thiosulfate for calcinosis cutis associated with autoimmune connective tissue diseases: the Mayo Clinic experience, 2012-2017. Clin Exp Dermatol 44:e189-e192. https://doi.org/10.1111/ced. 13782

32. von Hodenberg C, Neufeld M, Wohlrab J et al (2020) Topical sodium thiosulfate: a reliable treatment for digital calcinosis cutis - a case series with six patients. JDDG J Dtsch Dermatol Ges 18:1181-1183. https://doi.org/10.1111/ddg.14191

33. Urretavizcaya M, Lombera L, Irastorza B et al (2016) Elaboration of a $10 \%$ sodium thiosulfate w/o topical cream for the treatment of calcinosis cutis in two premature neonates. Eur J Hosp Pharm 23:A214. https://doi.org/10.1136/ejhpharm-2016-000875.485 
34. Eleryan M, Awosika O, Akhiyat S et al (2019) Treatment of calcinosis associated with adult and juvenile dermatomyositis using topical sodium thiosulfate via fractionated $\mathrm{CO}_{2}$ laser treatment. Clin Exp Rheumatol 37(6):1092-1093. Erratum in: Clin Exp Rheumatol 2020 38(1):174

35. Cannarozzo G, Bennardo L, Negosanti F, Nisticò SP (2020) CO2 laser treatment in idiopathic scrotal calcinosis: a case series. J Lasers Med Sci 11:500-501. https://doi.org/10.34172/jlms. 202079

36. Gunasekera NS, Gracey Maniar LE, Lezcano C et al (2017) Intralesional sodium thiosulfate treatment for calcinosis cutis in the setting of lupus panniculitis. JAMA Dermatol 153:944-945. https:// doi.org/10.1001/jamadermatol.2017.0966

37. Smith GP (2013) Intradermal sodium thiosulfate for exophytic calcinosis cutis of connective tissue disease. J Am Acad Dermatol 69:e146-e147. https://doi.org/10.1016/j.jaad.2013.03.022

38. Topham C, Haynes D, Frigerio A, Hull C (2019) Linear amyopathic dermatomyositis with calcinosis cutis responsive to topical sodium thiosulfate. Pediatr Dermatol 36:e102-e103. https://doi. org/10.1111/pde. 13868

39. Tajalli M, Qureshi AA (2019) Successful treatment of calcinosis cutis of fingertip in the setting of CREST syndrome with topical 20\% sodium thiosulfate. JAAD Case Rep 5:988-990. https://doi. org/10.1016/j.jdcr.2019.08.011

40. Karthik S, Bhatt A, Babu T (2019) Sodium thiosulfate dressings facilitate healing of refractory cutaneous ulcers of calcinosis cutis. J Postgrad Med 65:123-124. https://doi.org/10.4103/jpgm.JPGM_ 500_18

41. García-García E, López-López R, Álvarez-del-Vayo C, BernabeuWittel J (2017) Iatrogenic calcinosis cutis successfully treated with topical sodium thiosulfate. Pediatr Dermatol 34:356-358. https://doi.org/10.1111/pde.13116

42. Bhari N, Bharti P (2019) Dystrophic calcinosis cutis in autosomal recessive dystrophic epidermolysis bullosa. BMJ Case Rep. https://doi.org/10.1136/bcr-2019-231287

43. Lopez-Sundh AE, Quintana-Sancho A, Duran-Vian C et al (2021) Clinical and ultrasound response to intralesional sodium thiosulfate for the treatment of calcinosis cutis in the setting of systemic sclerosis. A case-based review. Clin Rheumatol. https://doi.org/ 10.1007/s10067-020-05523-4

44. Aristizabal M, Aristizabal J, Giraldo D et al (2020) Milia-like idiopathic calcinosis cutis of the forehead in an adult without Down's syndrome successfully treated with a CO2 laser. J Cosmet Dermatol 19:102-104. https://doi.org/10.1111/jocd.13233

45. Zarate G, Piva MMM, Hernandez BA et al (2017) Treatment of calcinosis cutis with CO2 laser. Int J Dermatol 56:1269. https:// doi.org/10.1111/ijd.13720

46. Perez-Moreno MA, Alvarez Del Vayo-Benito C, Villalba-Moreno AM et al (2014) CP-117 Severe calcinosis cutis successfully treated with a topical W/O emulsion of $10 \%$ sodium thiosulfate. Eur J Hosp Pharm Sci Pract 21:A47-A47. https://doi.org/10.1136/ ejhpharm-2013-000436.115

47. Wolf EK, Smidt AC, Laumann AE (2008) Topical sodium thiosulfate therapy for leg ulcers with dystrophic calcification. Arch Dermatol 144:1560-1562. https://doi.org/10.1001/archderm.144. 12.1560

48. Pagnini I, Simonini G, Giani T et al (2014) Sodium thiosulfate for the treatment of calcinosis secondary to juvenile dermatomyositis. Clin Exp Rheumatol 32:408-409

49. Weig EA, Roth GM, Ferguson NN (2019) Subepidermal calcified nodule on the periungual finger successfully treated with ablative carbon dioxide laser. Pediatr Dermatol 36:262-264. https://doi. org/10.1111/pde.13742

50. Kutlubay Z, Yardimci G, Gokler G, Engin B (2014) A dystrophic calcinosis cutis case treated with $\mathrm{CO} 2$ laser. J Cosmet Laser Ther 16:144-146. https://doi.org/10.3109/14764172.2013.854622
51. Joo YH, Kwon IH, Huh CH et al (2004) A case of persistent subepidermal calcified nodule in an adult treated with $\mathrm{CO} 2$ laser. $\mathbf{J}$ Dermatol 31:480-483. https://doi.org/10.1111/j.1346-8138.2004. tb00537.x

52. Chamberlain AJ, Walker NPJ (2003) Successful palliation and significant remission of cutaneous calcinosis in CREST syndrome with carbon dioxide laser. Dermatol Surg 29:968-970. https://doi. org/10.1046/j.1524-4725.2003.29261.x

53. Meissner M, Ochsendorf F, Kaufmann R (2010) Letter: Therapy of calcinosis cutis using erbium-doped yttrium aluminum garnet laser treatment. Dermatol Surg 36:727-728. https://doi.org/10. $1111 / \mathrm{j} .1524-4725.2010 .01539 . x$

54. Wollina U (2012) Treatment of multiple scrotal cysts with a $910 \mathrm{~nm}$ short-pulsed diode laser. J Cosmet Laser Ther 14:159160. https://doi.org/10.3109/14764172.2012.687111

55. Abrouk M, Noussari Y, Waibel JS (2020) Novel treatment of calcifications from dermatomyositis with picosecond and carbon dioxide laser. JAAD Case Rep 6:852-853. https://doi.org/10.1016/j. jdcr.2020.06.022

56. Chan AYK, Li E (2005) Electric shock wave lithotripsy (ESWL) as a pain control measure in dermatomyositis with calcinosis cutis—old method, new discovery. Clin Rheumatol 24:172-173. https://doi.org/10.1007/s10067-004-1023-3

57. Delgado-Márquez AM, Carmona M, Vanaclocha F, Postigo C (2015) Effectiveness of extracorporeal shock wave lithotripsy to treat dystrophic calcinosis cutis ulcers. Actas Dermosifiliogr 106:140-143. https://doi.org/10.1016/j.ad.2014.06.006

58. Pavlov-Dolijanovic S, Stupar NV, Zeljkovic S et al (2019) Calcifications associated with limited systemic sclerosis and psoriatic arthritis by extracorporeal shock wave lithotripsy and intralesional injections of sodium thiosulphate: case report. Osteoporos Int 30:S305-S305

59. Abbott J, Kowalski EH, Klein S et al (2020) Iatrogenic calcinosis cutis secondary to calcium chloride successfully treated with topical sodium thiosulfate. JAAD Case Rep 6:181-183. https://doi. org/10.1016/j.jdcr.2019.12.017

60. Peng T, Zhuo L, Wang Y et al (2018) Systematic review of sodium thiosulfate in treating calciphylaxis in chronic kidney disease patients. Nephrol Carlton Vic 23:669-675. https://doi.org/10. 1111/nep. 13081

61. Cicone JS, Petronis JB, Embert CD, Spector DA (2004) Successful treatment of calciphylaxis with intravenous sodium thiosulfate. Am J Kidney Dis 43:1104-1108. https://doi.org/10.1053/j.ajkd. 2004.03.018

62. Reiter N, El-Shabrawi L, Leinweber B et al (2011) Calcinosis cutis: part II. Treatment options. J Am Acad Dermatol 65:15-22. https://doi.org/10.1016/j.jaad.2010.08.039

63. del Barrio-Díaz P, Moll-Manzur C, Álvarez-Veliz S, Vera-Kellet C (2016) Topical sodium metabisulfite for the treatment of calcinosis cutis: a promising new therapy. Br J Dermatol 175:608-611. https://doi.org/10.1111/bjd.14412

64. Patra S, Gupta V, Kumar R, Verma KK (2017) Clinical and radiological improvement in idiopathic calcinosis cutis with topical 25\% sodium metabisulfite. Int J Dermatol 56:1464-1465. https:// doi.org/10.1111/ijd.13789

65. Mittermayr R, Antonic V, Hartinger J et al (2012) Extracorporeal shock wave therapy (ESWT) for wound healing: technology, mechanisms, and clinical efficacy. Wound Repair Regen 20:456465. https://doi.org/10.1111/j.1524-475X.2012.00796.x

Publisher's Note Springer Nature remains neutral with regard to jurisdictional claims in published maps and institutional affiliations. 